\title{
Research on the Identification of Carcinogenic Substances in Some Environmental Components in Ilfov County
}

\author{
Alexandru SUPEANU ${ }^{1}$, Nastasia BELC ${ }^{2}$, Cristian DUICU ${ }^{1}$, Teodora SUPEANU $^{3}$ \\ ${ }^{1}$ Stefan S. Nicolau Institute of Virology of the Romanian Academy, 285 Mihai Bravu Avenue, District 3, \\ Zip Code 030304, Bucharest, Romania, criomedical@gmail.com, cristiduicu@yahoo.com \\ ${ }^{2}$ The National Institute of Research\&Development for Food Bioresources , 6 Dinu Vintila street, Zip \\ Code 021102, Bucharest, Romania, nastasia.belc@bioresurse.ro \\ ${ }^{3}$ The Faculty of Veterinary Medicine in Bucharest, 105 Independentei Road, Zip Code 050097, \\ Bucharest, Romania, supeanu.teodora@gmail.com \\ *corresponding author, e-mail: criomedical@gmail.com
}

Bulletin UASVM series Agriculture 73(1)/2016

Print ISSN 1843-5246; Electronic ISSN 1843-5386

DOI 10.15835/buasvmcn-agr: 12019

\begin{abstract}
Identifying potentially carcinogenic substances in the environment represents the primary action step that should be taken in order for us to claim to have a healthy and safe agriculture. Unfortunately, this is not always the case and our foods and waters may not be as safe as we believe them to be. The present elaborate had the purpose of identifying possible carcinogenic contaminants, in a direct correlation with the culture environment - water source and soil, in Ilfov county, Romania. Water: 14 samples were collected from household wells, targeted for the analysis of various chemical and physical parameters, including nitrates, nitrites, pesticides, dioxins, furans, etc. The results have shown a scattered level of pollution with nitrates of the groundwater aquifers, due to the incorrect administration of fertilizers that has especially affected the individual wells from the investigated areas. Soil: 32 crop soil samples were harvested from the upper level $(0-20 \mathrm{~cm}$, belonging to the same areas as the water samples. Various quantities of mineral nitrogen were determined, either as nitrates or as nitrites. No carcinogens, from the groundwater aquifers investigated, with sufficient levels to contaminate the soil and affect the agricultural products were identified. The analysed water is fit for agricultural irrigations, but is not to be used for human consumption. For soils, the extremely spread distribution of the nitrogen proves that the nitrogen based fertilizers are being used in an irrational manner, thus the danger for environment pollution and for the alteration of animal and human health. The presence of potentially toxic metals was also investigated, elements that, except for arsenic, turned out to be within normal limits.The investigated elements from the Berceni, Glina, Popești-Leordeni and Ulmi areas do not present any significant dangerous quantities which proved the fact that the local agricultural technology is functioning normally, producing vegetal and animal foods free of elements with a potentially carcinogenic effect. The rest of the investigated areas, respectively Buda, Bragadiru, Măgurele, Vidra and Copăceni, have shown the presence of potentially carcinogenic elements that exceed the normal limit, most likely based on an improperly implemented agricultural technology.
\end{abstract}

Keywords: carcinogens, environment, water, soil

\section{INTRODUCTION}

Preventing the cancer disease represents a public interest activity that holds an extremely important consequence for an adequate quality of life. The directions in which it is acted for cancer prevention include, among other, prevention and reducing the risk of contamination of humans and animals with cancer risk factor coming from the environment. To correctly and completely evaluate these actions, it is necessary to study all of the environment components: air, soil, water, plants, animals and the way in which their quality reflects 
upon the welfare of humans and animals. Only then can we discuss about "healthy food", "healthy life" and include these elements into the "ONE HEALTH" concept. The present study reflects part of the status of the degree of pollution of water and soil with carcinogenic substances and other toxic substances, in the surrounding communes of Bucharest, the capital of Romania, looked upon from an oncology point of view.

\section{MATERIALS AND METHODS Water sampling}

14 water samples were collected from household wells, to the purpose of investigating the pollution levels with carcinogenic and toxic elements of water used for watering crops in the households from the southern part of the Ilfov county, including two surface water samples, one from the Sabar river and one from the Dambovita river (Glina), two groundwater samples (raw and filtered) from Ulmi, Giurgiu county. The groundwater samples were sampled from wells that had around 7 meters in depth, the deepest reaching 20 meters.

\section{Water samples analysis}

The physical and chemical parameters investigated for the water samples were: $\mathrm{pH}$, nitrites, nitrates, PAHs, organochlorine, triazine and organophosphorus pesticides, halogenated organic compounds and VOCs, BTEX, metals, as well as dioxins and furans.

Tab. 1. Groundwater quality standards - nitrates, pesticides

\begin{tabular}{|c|c|}
\hline Pollutants & $\begin{array}{c}\text { Quality } \\
\text { standards }\end{array}$ \\
\hline Nitrates & $50 \mathrm{mg} / \mathrm{L}$ \\
\hline $\begin{array}{c}\text { Active substances from pesticides, } \\
\text { including metabolites, degradation } \\
\text { products and relevant reaction } \\
\text { products }^{1)}\end{array}$ & $\begin{array}{c}0,1 \mu \mathrm{g} / \mathrm{L} \\
0,5 \mu \mathrm{g} / \mathrm{L}(\text { total) }\end{array}$ \\
\hline $\begin{array}{l}\text { 1) Pesticides referring to the plant } \\
\text { protection substances and to the } \\
\text { biocides. } \\
\text { 2) Total referring to the sum of all } \\
\text { detected pesticides and quantified in } \\
\text { the monitoring procedure, including } \\
\text { the metabolites, degradation and } \\
\text { relevant reaction products. }\end{array}$ & \\
\hline
\end{tabular}

\section{waters}

Quality standards for the investigated

The groundwater quality standards according to the Government Decision 53 of 2009 are the following:

The investigation and evaluation of the pollution degree for the groundwater had in view the following substances, covered by the Government Decision 449 of 2013, as an addition to the Government Decision 53, 2009. The other laws that regulate the water quality are the Law for water protection 107, 1996, modified by the laws 310 of 2004, 112 of 2006, and the Government Emergency Ordinance 3 of 2010.

The quality standards for the relevant and priority hazardous substances are covered by the Annex to the Order 161 of 2006.

Depending on the toxic and hazardous indicators, irrigation rules, climatic conditions and soil texture, water used for watering crops is sorted (STAS 9450-88) into:

type I, for high volumes of irrigations, usable in dry areas with a fine to coarse soil texture;

type II, for low volumes of irrigations, usable wetlands with a fine soil texture;.

\section{Soil samples analysis}

The soil samples gathered from the southeastern adjacent area of Bucharest, from field crops were analyzed in a specialized laboratory, following the standard procedure:

- $\mathrm{pH}$ determination, determination of organic carbon, determination of total nitrogen,

Tab. 2. Critical thresholds for the groundwater contamination

\begin{tabular}{cc}
\hline Name of the substance & $\begin{array}{c}\text { Critical values } \\
(\boldsymbol{\mu g} / \mathbf{L})\end{array}$ \\
\hline Benzene & 10 \\
\hline Toluene & 100 \\
\hline Ethylbenzene \\
30 \\
\hline Xylenes (sum) \\
\hline Trichloroethylene \\
\hline Tetrachloroethylene \\
\hline Naphtalene \\
\hline MTBE (methyl tertiary-butyl ether) \\
\hline Total petroleum hydrocarbons (TPH) & 10 \\
\hline Vinyl chloride & 10 \\
\hline
\end{tabular}


determination of nitrates (N-NO3), determination of nitrites (N-NO2), determination of the content of mobile forms of phosphorus and potassium, determination of total forms of nickel (Ni), chromium (Cr), cadmium $(\mathrm{Cd})$, lead $(\mathrm{Pb})$ and arsenic (As), determination of polynuclear aromatic hydrocarbons by high performance liquid-phase chromatography, determination of

Tab. 3. Surface water quality standards - Heavy metals

\begin{tabular}{ccc}
\hline No. & Indicator & Quality standard $(\boldsymbol{\mu g} / \mathbf{L})$ \\
\hline 1 & Arsenic & 7,2 \\
\hline 2 & Barium & 200 \\
\hline 3 & Beryllium & 0,05 \\
\hline 4 & Boron & 1000 \\
\hline 5 & Cadmium & 1 \\
\hline 6 & Cobalt & 0,7 \\
\hline 7 & Chromium & 2,5 \\
\hline 8 & Copper & 1,3 \\
\hline 9 & Mercury & 1 \\
\hline 10 & Molybdenum & 3,6 \\
\hline 11 & Nickel & $2,1 / 1,3$ \\
\hline 12 & Lead & $1,7 / 0,4$ \\
\hline 13 & Selenium & 0,07 \\
\hline 14 & Tin & 2,2 \\
\hline 15 & Thallium & 2 \\
\hline 18 & Vanadium & 1,2 \\
\hline
\end{tabular}

Tab. 4. Surface water quality standards - PAHs

\begin{tabular}{ccc}
\hline No. & Indicator & $\begin{array}{c}\text { Quality standard } \\
(\boldsymbol{\mu g} / \mathbf{L})\end{array}$ \\
\hline 1 & Benzo (b) fluoranthene & 0,025 \\
\hline 2 & Benzo (k) fluoranthene & 0,025 \\
\hline 3 & Benzo (g, h, i) perylene & 0,025 \\
\hline 4 & Indeno (1,2,3-cd) pyrene & - \\
\hline 5 & PAHs sum of indicator 3 & 0,016 \\
\hline 6 & and 4 & 0,01 \\
\hline 7 & Benzo (a) anthracene & 0,05 \\
\hline 8 & Fluoranthene & 0,09 \\
\hline 9 & Naphthalene & 2,4 \\
\hline 10 & Phenanthrene & 0,03 \\
\hline 11 & Anthracene & 0,063 \\
\hline
\end{tabular}

organochlorine insecticides (HCH and DDT), by gas chromatography.

\section{RESULTS AND DISCUSSIONS \\ The ground water samples (wells)}

- The $\mathrm{pH}$ of the samples was neutral, between 6,68 and 7,38;

- The nitrites values ranged from $0,004 \mathrm{mg} / \mathrm{L}$ to $0,031 \mathrm{mg} / \mathrm{L}$; the groundwater from the Berceni commune presents a higher level of nitrites, reaching the value of $1,63 \mathrm{mg} / \mathrm{L}$;

Tab. 5. Surface water quality standards - solvents

\begin{tabular}{ccc}
\hline No. & Indicator & $\begin{array}{c}\text { Quality standard } \\
(\boldsymbol{\mu g} / \mathbf{L})\end{array}$ \\
\hline 1 & $1,1,1$-trichloroethane & 10 \\
\hline 2 & $1,1,2$-trichloroethane & 10 \\
\hline 3 & 1,1,2,2-tetrachloroethane & 10 \\
\hline 4 & 1,1 -dichloroethane & 10 \\
\hline 5 & 1,2-dichloroethane & 10 \\
\hline 6 & 1,1-Dichloroethene & 10 \\
\hline 7 & 1,2 -Dichloroethene & 10 \\
\hline 8 & Trichlorobenzene (sum) & 0,4 \\
\hline 9 & $1,2,4,5$-tetrachlorobenzene & 10 \\
\hline 10 & 1,2-dibromomethane & 2 \\
\hline 11 & 1,2-dichlorobenzene & 10 \\
\hline 12 & 1,3-dichlorobenzene & 1 \\
\hline 13 & 1,4-dichlorobenzene & 10 \\
\hline 14 & Dichloromethane & $10 / 8,2$ \\
\hline 15 & Benzene & 1 \\
\hline 16 & Chlorobenzene & 1 \\
\hline
\end{tabular}

Tab. 5. Surface water quality standards - solvents - continued

\begin{tabular}{ccc}
\hline No. & Indicator & $\begin{array}{c}\text { Quality standard } \\
(\boldsymbol{\mu g} / \mathbf{L})\end{array}$ \\
\hline 17 & Chloroform & 10 \\
\hline 18 & Vinyl chloride & 2 \\
\hline 19 & Epichlorohydrin & 10 \\
\hline 20 & Ethylbenzene & 10 \\
\hline 21 & Tetrachloroethene & 10 \\
\hline 22 & Trichlorethylene & 10 \\
\hline 23 & o, m, p-xylenes & $10($ each) \\
\hline 24 & Carbon tetrachloride & 7,2 \\
\hline 25 & Hexachlorobutadiene & 0,003 \\
\hline
\end{tabular}


- the nitrates values ranged from $22,1 \mathrm{mg} / \mathrm{L}$ to $361,4 \mathrm{mg} / \mathrm{L}$; in most of the samples, the values topped the maximum admitted levels of 50 $\mathrm{mg} / \mathrm{L}$;

- Dichloromethane was detected in the groundwater samples in concentrations ranging from $3,00 \mu \mathrm{g} / \mathrm{L}$ to $9,49 \mu \mathrm{g} / \mathrm{L}$;

- Out of the 16 compounds belonging to the PAHs group, Pyrene and Benzo (g, h, i) perylene were detected in most samples, in relatively low concentrations, that stand below the maximum admitted levels.

- The concentrations of the metals analyzed were low, standing below the maximum admitted levels; the most commonly found metals were $\mathrm{Cu}, \mathrm{Ba}, \mathrm{Ni}, \mathrm{Se}, \mathrm{Zn}$, and boron.

\section{The surface water samples}

- Dichloromethane was detected in the surface water samples from Dambovita $(154,03 \mu \mathrm{g} / \mathrm{L})$

Tab. 6. Surface water quality standards organochlorine pesticides

\begin{tabular}{ccc}
\hline No. & Indicator & Quality standard $(\boldsymbol{\mu g} / \mathbf{L})$ \\
\hline 1 & Alachlor & 0,035 \\
\hline 2 & Aldrin & 0,01 \\
\hline 3 & Dieldrin & 0,01 \\
\hline 4 & Endrin & 0,005 \\
\hline 5 & Endrin aldehyde & - \\
\hline 6 & Isodrin & 0,005 \\
\hline 7 & Heptachlor & 0,0002 \\
\hline 8 & Heptaclorepoxid & - \\
\hline 9 & $\alpha$-HCH (lindane) & 0,02 \\
\hline 10 & $\beta$-HCH & - \\
\hline 11 & $\gamma$-HCH & - \\
\hline 12 & $\delta$-HCH & - \\
\hline 13 & HCH sum & 0,042 \\
\hline 14 & Endosulfan I (alpha) & 0,00002 \\
\hline 15 & endosulfan II (beta) & $0,004($ sum of 14 and 15$)$ \\
\hline 16 & Endosulfan sulfate & - \\
\hline 17 & DDE, $4,4^{4}$-isomer & - \\
\hline 18 & DDE, $2,4^{4}$-isomer & - \\
\hline 19 & DDD, $4,4^{\prime}$-isomer & 0,01 \\
\hline 20 & DDD, $2,4^{\prime}$-isomer & - \\
\hline 21 & DDT, $4,4^{\prime}$-isomer & - \\
\hline 22 & DDT, $2,4^{\prime}$-isomer & - \\
\hline 23 & DDT (sum of 1-6) & 0,025 \\
\hline & & \\
\hline
\end{tabular}

and Sabar $(27,82 \mu \mathrm{g} / \mathrm{L})$ rivers, in concentrations that exceed the value of the quality standards regarding surface water protection; also, in the sample from the Dambovița river, 1,1,1-trichloroethane was found in a low concentration $(0,41 \mu \mathrm{g} / \mathrm{L})$;

- Benzo (g, h, i) perylene was detected in surface water samples from the two rivers, in concentrations that do not exceed the maximum admitted levels;

- The Copper concentrations in both samples exceed the maximum admitted levels of 1,3 $\mu \mathrm{g} / \mathrm{L}$.

\section{The soil samples}

A constant exceeding of the maximum admitted levels of pollution is present in the case of microelements with a toxic potential, respectively $\mathrm{Cr}, \mathrm{Pb}, \mathrm{Ni}$ and $\mathrm{As}$, as much as three times the maximum admitted levels.

The PAHs exceed the maximum admitted levels of pollution up to five times in the case of Jilava commune, almost meeting the required concentration to reach the alert and intervention benchmarks.

The polychlorinated biphenyls compounds exceed the maximum admitted levels of pollution up to nine times, without meeting the required concentration to reach the alert and intervention benchmarks.

Tab. 7. Surface water quality standards - triazine and organophosphorus pesticides

\begin{tabular}{lcc}
\hline No. & Indicator & Quality standard $(\boldsymbol{\mu g} / \mathbf{L})$ \\
\hline \multicolumn{3}{c}{ Triazine pesticides } \\
\hline 1 & Simazine & 1 \\
\hline 2 & Triazophos & 0,03 \\
\hline 3 & Atrazine & 0,34 \\
\hline & Organophosphorus pesticides \\
\hline 4 & Dichlorvos & - \\
\hline 5 & Methamidophos & 0,1 \\
\hline 6 & Mevinphos & 0,0002 \\
\hline 7 & Diazinon & - \\
\hline 8 & Parathion-methyl & 0,0002 \\
\hline 9 & Parathion-ethyl & 0,0002 \\
\hline 10 & Malathion & 0,0002 \\
\hline 11 & Chlorpyrifos & 0,00046 \\
\hline 12 & Chlorfenvinphos & 0,06 \\
\hline
\end{tabular}




\section{Determining the dioxin content in soils}

In 3 of the soil samples harvested for analysis, the contents of dioxin and furans were determined. The values obtained are within normal parameters, below the alert and intervention thresholds set by the Order 756 of 1997.

Tab. 8. Irrigation water quality standards

\begin{tabular}{|c|c|c|}
\hline \multirow{3}{*}{ Indicator } & \multicolumn{2}{|c|}{ Type } \\
\hline & I & II \\
\hline & \multicolumn{2}{|c|}{$\begin{array}{l}\text { Maximum permitted } \\
\text { concentration }(\mathrm{mg} / \mathrm{L})\end{array}$} \\
\hline Aluminum & 5,0 & 20,0 \\
\hline Arsenic & $0, .1$ & 2,0 \\
\hline Beryllium & 0,1 & 0,5 \\
\hline Boron & 0,75 & 2,0 \\
\hline Cadmium & 0,01 & 0,05 \\
\hline Cyanides & 0,2 & 0,2 \\
\hline Cobalt & 0,05 & 5,0 \\
\hline Chromium & 0,1 & 1,0 \\
\hline Copper & 0,2 & 5,0 \\
\hline Iron & 1,0 & 5,0 \\
\hline Fluorine & 1,0 & 5,0 \\
\hline Lithium & 2,05 & 2,5 \\
\hline Manganese & 0,2 & 3,0 \\
\hline Molybdenum & 0,01 & 0,05 \\
\hline Mercury & 0,02 & 0,05 \\
\hline Nickel & 0,2 & 2,0 \\
\hline Lead & 2,0 & 5,0 \\
\hline Selenium & 0,02 & 0,05 \\
\hline $\begin{array}{l}\text { Sulphides and hydrogen } \\
\text { sulfide }\end{array}$ & 0,1 & 0,5 \\
\hline Vanadium & 0,1 & 1,0 \\
\hline Zinc & 2,0 & 10,0 \\
\hline
\end{tabular}

\section{CONCLUSIONS}

It can be stated that, in the 8 communes that make up the adjacent area of Bucharest (Bragadiru, Măgurele, Vidra, Copăceni, Jilava, Berceni, Glina, Popești-Leordeni), the environment (soil, groundwater and surface water) presents a relatively low average degree of pollution, a fact that is extremely important and favourable to any field crops. As for the oncologic evaluation of some chemical substances, present in soil and water and that hold a high degree of cancer inducing risk, the following conclusions can be drawn:

The Berceni, Glina, Popeşti-Leordeni and Ulmi areas do not show significant levels of warning or exceeding the maximum admitted levels to the extent of enforcing the intervention measures. This leads to the conclusion that in these areas, a clean and normal agriculture is carried out, leading to safe food from a carcinogenic point of view.

On the other hand, the results from Bragadiru, Măgurele, Vidra, Copăceni and areas have shown constant exceeding of the maximum admitted levels in soil and water for chemicals that have a high carcinogenic potential. Under these conditions, it is necessary to inform and educate the population involved in agricultural activities, showing the risk they subject themselves by failing to meet the conditions of a „bio” agriculture.

The main recommendation to the population living in the second category of areas is to rationalize the use of fertilizer products and of biocides and to use the water from the wells only for crop irrigation and not for human consumption.

Tab. 9. Benchmarks for traces of chemicals in soils (Order no. 756 of1997)

\begin{tabular}{cccccc}
\hline \multirow{2}{*}{ Element } & \multirow{2}{*}{$\begin{array}{c}\text { Normal } \\
\text { values }\end{array}$} & \multicolumn{2}{c}{ Alert thresholds } & \multicolumn{2}{c}{ Intervention thresholds } \\
\cline { 2 - 6 } & & \multicolumn{2}{c}{ Types of usage } & \multicolumn{2}{c}{ Types of usage } \\
\cline { 2 - 6 } & Sensitive & Less sensitive & Sensitive & Less sensitive \\
\hline $\mathrm{Ni}$ & 20 & 75 & 200 & 150 & 500 \\
\hline $\mathrm{Cr}$ & 30 & 100 & 300 & 300 & 600 \\
\hline $\mathrm{Cd}$ & 1 & 3 & 5 & 5 & 10 \\
\hline $\mathrm{Pb}$ & 20 & 50 & 250 & 100 & 1.000 \\
\hline $\mathrm{As}$ & 5 & 15 & 25 & 25 & 50 \\
\hline
\end{tabular}




\section{REFERENCES}

1. STAS 9450-88;

2. The Government Decision no. 53 from the $29^{\text {th }}$ of January 2009 regarding the approval of the national plan for the protection of the groundwater against pollution and deterioration, modified by the Government Decision no. 449 from the $4^{\text {th }}$ of July 2013;
3. The law for water protection no. $107 / 1996$, modified by the laws no. 310/2004, 112/2006, and the Government Emergency Ordinance no. 3/2010;

4. The Order of the Minister of Environment and Water Management no. 161/2006, regarding the classification of the surface water quality;

5. The order of the Minister of Waters, Forests and Environment Protection no. 756/1997, regarding the benchmarks for traces of chemicals in soils. 